\title{
Judicial diversity, the woman judge and fairy tale endings
}

\author{
Erika Rackley* \\ Department of Law, Durham University
}

The story of the woman judge as one of exclusion and isolation plagued with allegations of bias is well documented. Interestingly, despite significant differences in time and place, a common theme unites these tales: the woman judge is a dangerous outsider, a threat to the aesthetic norm. The judicial climate, at least in most of the common law world, is somewhat chilly: reactions to her presence on the bench vary from the largely indifferent to the downright hostile. Why is this? After all, most people, perhaps acknowledging the political and democratic gains underlying calls for a more representative judiciary, would wish to encourage - or at least not discourage - judicial diversity.

Taking the stories of the woman judge as its starting point, this paper contends that underlying these tales is an image of the judge that is as much intuitive as it is reasoned; that our understanding of the judge and judging is as much derived from the imagination as from what is conventionally considered as rational thought. Thus, the paper deploys the narrative strategies of fairy tales in an attempt to disrupt the imaginative hold of familiar yet particular images that infuse and distort current discourses on adjudication. It suggests that despite the Department for Constitutional Affairs' ongoing quest to increase diversity within the judiciary, current initiatives do not confront fully these instinctive images. As a result, their narrative of inclusiveness and difference fails. In response, the paper appeals to the imagination as a route toward engendering new conceptions on the judge and judging, the possibility of truly diverse judiciaries and, perhaps, a fairy tale ending to the woman judge's story.

\section{INTRODUCTION}

Psst! Did you hear about the law faculty who refused a woman's application to become a student because her presence would 'distract the attention of the young men'? ${ }^{1}$ Or, about the attempt to challenge a planning tribunal's decision on the grounds that the 'tribunal was pregnant'? ${ }^{2}$ How about the one about the female magistrate whose judgment was challenged on the grounds that she was not a 'person'? $?^{3}$ Surely, you must have heard about the US Supreme Court judge who, as

* I would like to thank Joanne Conaghan, Clare McGlynn and Neil Cobb for their support, intellectual generosity and conversation as well as the anonymous referees for their helpful comments on an earlier draft of this paper. The usual caveats apply.

1. L Dusky Still Unequal - The Shameful Truth about Women and Justice in America (New York: Crown Publishers, 1996) p 16, quoted in C McGlynn The Woman Lawyer-Making the Difference (London: Butterworths, 1998) p 7.

2. B Naylor 'Pregnant tribunals' (1989) 14(1) Legal Service Bulletin 41.

3. D Bright "The other woman: Lizzie Cyr and the origins of the "Persons Case", (1998) 13 Can JL \& Soc 99 at 112. 
a law student, graduated third in her class and was offered a job in a top US law firm - as a legal secretary? $?^{4}$ And, about the judge whose nicotine habit gave rise to allegations of bias? $?^{5}$ What about the stories about the justice minister who tried to introduce quotas in order to ensure a gender balance within his judiciary because there were simply too many female judges, ${ }^{6}$ or about the Chief Magistrate whose management style landed her in jail $?^{7}$

In her introduction to From the Beast to the Blonde, Marina Warner begins her consideration of fairy tales and their tellers with a Kenyan fairy tale from Angela Carter's first anthology. ${ }^{8}$ The story is about two wives; one is married to the Sultan, the other to a poor villager. While the villager's wife thrives, the Sultana gradually wastes away. The Sultan summons the poor wife's husband and demands to know the secret of his wife's happiness. 'Very simple', the villager replies, 'I feed her the meat of the tongue'. When, after lavishing his wife with all the many varieties of tongue money can buy she still does not flourish, the Sultan orders the wives to change places. Once in the village, the Sultan's wife immediately thrives, while her replacement languishes in the palace. Of course, the tongue meat the poor husband feeds the women is not material, but rather that of 'fairy tales, stories, jokes, songs: he nourishes them on talk... he banishes melancholy by refusing silence. Storytelling makes women thrive - and not exclusively women, the Kenyan fable implies, but other sorts of people, too, even sultans'. ${ }^{9}$ Even, perhaps, lawyers?

It seems without the meat of the tongue we are destined to wither and fade. Stories not only nourish us as individuals, but also bring people together. Consider, for example, bedtime stories, campfire tales, news reports, judgments, conference papers and so on. Stories invite people in, offering explanations as to how things are and opening avenues onto how things might be. Put simply, we tell stories in order to belong, to nurture connections and establish relationships; when we tell a story we become part of that tale as it becomes, at least for a time, our story. ${ }^{10}$

So viewed, it is perhaps unsurprising that the story of the woman lawyer and judge as largely one of isolation, hostility and exclusion has been well documented. The

4. RM Salokar and M Wilson 'Sandra Day O'Connor' in RM Salokar and ML Volcansek (eds) Women in Law: A Bio-Bibliographical Sourcebook (Westport: Greenwood Press, 1996) pp 210 and 211.

5. Canadian Judicial Council Judicial Council Closes File in Complaint Against BC Madam Justice Southin 21 March 2003.

6. A Sage 'Women rule in French courts' New Statesman 29 September 2003.

7. R Hunter 'Fear and loathing in the sunshine state' (2004) 19(44) Aus Feminist Studies 145.

8. Anon 'Tongue meat' in A Carter (ed) The Virago Book of Fairy Tales (London: Virago Press, 1990) p 215.

9. M Warner From the Beast to the Blonde: On Fairy Tales and their Tellers (London: Vintage, 1995) p i.

10. 'We' and 'our' may capture a number of communities here in line with my understanding of storytelling, especially of those stories described as 'fairy tales', as a predominantly female activity which crosses and subverts - cultural, historical, geographical, political, social boundaries (A Carter 'Introduction' in A Carter (ed) Angela Carter's Book of Fairy Tales (London: Virago Press, 2005) pp xi-xxiv and, generally, Warner, above n 9). However, although I seek throughout my paper, in both its content and style, to invoke this relationship, I recognise that in so doing I risk not only over- and under-inclusiveness but also giving the "constitutive we' the appearance of a coherence it does not posses (KL Scheppele 'Foreword: telling stories' (1989) 87 Mich L Rev 2073 at 2077-2085). As the tales of Cinderella, Snow White and others reveal 'sisters ... we might be, but that doesn't mean we've got much in common' (Carter, ibid, pp xvi and 167-214). 
tales where, once upon a time, feisty heroines took on the misogynistic villains and kindly guardians intent on thwarting their entrance to, and determining their adventures in, Law's Empire have become the stuff of folklore told from one generation to the next. As such, they are both unnerving and reassuring. While we recognise the struggles of our pioneer heroes, like the plots and characters of childhood fairy tales, their stories seem belong to a different time; a time before the struggle for equality was won, when difference was synonymous with danger and an outsider was immediately suspicious. After all, nowadays, the 'outsider' judge is positively welcomed; diversity within the legal profession, and especially in the judiciary, is increasingly not merely desirable but essential - isn't it? In short, we all know the ending to this particular story - the woman judge is living happily every after with her Herculean prince. Isn't she?

Well, no. Not really. In fact, there is a growing collection of tales suggesting that more often than not the woman judge is still waiting for that elusive happy ending. Nevertheless, these stories perhaps have more in common with fairy tales than we might, at first, expect. Like the narratives of more traditional tales, their familiar yet different characters and varyingly predictable plotlines span time zones, cultures, jurisdictions and even centuries. In some, the woman judge is alone, a remote beacon in a hostile environment or trailblazer willing, if able, to make a difference. While in others, the arrival of sisterly companionship serves only to emphasise the deafening silence that pervades her story. Moreover, in the same way that the talking wolves and gingerbread houses have led to commonplace understandings of fairy tales as foolish stories or childhood fantasies reliant on improbabilities and lacking integrity or foundation, ${ }^{11}$ the scenarios faced by the woman judge in these tales often defy belief; they too seem too incredible to be true. Hence, we tend to dismiss or downplay them as, at best, exaggerations and, at worst, exceptions.

Taking these tales of the woman judge as its starting point, this paper seeks to harness the power of storytelling. To this end, the tales of the woman judge told here are neither definitive nor representative but rather illustrative and indicative. Their power lies not in their literal or historical accuracy - although this is not in doubt but rather in the extent to which, like fairy tales, they 'disrupt the apprehensible world in order to open spaces for dreaming alternatives'. ${ }^{12}$ Embracing this potential for subversion, the paper frees these tales from the confines of their traditional role as whispered anecdotes or intriguing opening gambits, allowing them to haunt and effect its narrative. It establishes them as fairy tales, deliberately invoking their conversational style in order to provoke debate about the judge, diversity and the judiciary. In so doing, it seeks to expose stories, narrative and imagination as not only tools through which to consider the traditional understandings of the judge and judging, but also an integral component of them. Put another way, the paper contends that underlying both the tales of the woman judge and the Department for Constitutional Affairs' current quest to increase diversity within the judiciary is an image of the judge, which is as much intuitive as it is reasoned; that our understanding of the judge and judging is as much derived from the imagination as from what is conventionally considered as rational thought. As a result, despite significant differences in terms of time and place, our fairy tale protagonist is consistently characterised as a suspicious interloper or dangerous outsider. Her inescapable deviance from the judicial norm disrupts the homogeneity of the bench, revealing the unavoidable, yet largely unacknowledged,

11. Carter, ibid, pp xiii-xiv.

12. Warner, above $\mathrm{n} 9$, p xvi. 
gender dimension to traditional understandings of adjudication: 'the voice of the woman/judge, within the rhetorical context of adjudication, becoming its own dangerous supplement (woman/judge)' ${ }^{13}$

The paper goes on to suggest that despite the Department for Constitutional Affairs' rhetoric purporting to embrace and encourage judicial diversity, current initiatives do not confront fully the extent to which these familiar yet particular images of the judge and judging continue to infuse and distort current discourses on adjudication. The Department for Constitutional Affairs, like the Sultan, fails to recognise the importance of the meat of the tongue; it overlooks the promise of stories as a means of nourishment and, in so doing, creates narratives of inclusiveness and difference that are ultimately unsatisfying. In response, the paper appeals to the imagination and, in particular, the transformative possibilities of diversity as a route toward engendering new conceptions on the judge and judging and, perhaps, a fairy tale ending to the woman judge's story.

\section{TELLING TALES}

Did you hear about the judge who, on her appointment to the bench, received the traditional honorary membership of the Tattersall's Club, Australia's self-proclaimed premier private members' club, only to find this hastily withdrawn once they realised she was a woman $?^{14}$ Or about the female judge who was expected to retire to another room with her female guest after dinner whilst staying at the official judicial lodgings so that her male colleagues could enjoy their port and conversation unencumbered? ${ }^{15}$ What about the plot by a superhero pro-father pressure group to kidnap the dog belonging to the (former) President of the Family Division in order to show their displeasure with her perceived anti-father stance $?^{16}$ Although this is, arguably, nothing compared to the vitriolic and highly personal attacks against Claire L'HeureuxDubé by a fellow judge in the Canadian media following her judgment in $\mathrm{R} \mathrm{v}$ Ewanchuk. ${ }^{17}$

Storytelling, the Kenyan tale suggests, is good for the soul. Cast well, the 'magic spell of a good story' can bewitch the reader - the enchanted narrative transporting them beyond the ordinary, suspending disbelief, and capturing and enriching the imagination. ${ }^{18}$ Stories offer a moment of escape, of detachment or freedom, fostering feelings of inclusion, communication or belonging. Stories inspire, restore, transform, rescue, exclude and disrupt. The telling of stories opens windows both 'onto the

13. S Berns To Speak as a Judge - Difference, Voice and Power (Dartmouth: Ashgate, 1990) p 203.

14. M Thornton Dissonance and Distrust: Women in the Legal Profession (Oxford: Oxford University Press, 1996) p 167.

15. Brenda Hale interviewed in E Cruickshank (ed) Women in the Law: Strategic Career Management (London: The Law Society, 2003) p 135.

16. J Elliot 'Justice father talked of "suicide in front of Blair"' Sunday Times 22 January 2006.

17. [1999] 1 SCR 330; Canadian Judicial Council News Release 'Council releases response to REAL Women of Canada' 1 April 1999 and 'Panel expresses strong disapproval of McClung conduct' 21 May 1999.

18. GR Powell 'Opening statements: the art of storytelling' (2001) 31 Stetson L Rev 89 at 89-90. 
worlds we do not and can not live in ${ }^{19}$ and 'into reality', ${ }^{20}$ allowing us to explore the world in which we do:

'When we tell stories, we not only convey information, but we share a piece of history; we expand not only our knowledge of what happened, of what someone did, but also of why and how they did it, of how it felt, why it seemed necessary, how it fits into a worldview ... We learn what it is to walk in another's shoes, to experience another's pain, to anticipate another's pleasures, and by so learning we enlarge our own individual humanity and our society's sense of inclusion. ${ }^{21}$

Put another way, when we listen to stories and allow ourselves to climb into and walk around in the skin of others, we not only begin to understand their world differently, but ours too. Stories encourage empathy and acknowledge diversity; more than simply tales to idle away the hours, their narratives, constituted by and a component of their time, are mechanisms for and of change.

It is then perhaps unsurprising that 'the notion that storytelling is ubiquitous in the law - and in human interactions generally - has recently attained something like the status of a truth universally acknowledged' among legal academics. ${ }^{22}$ Legal feminists and critical race theorists especially have embraced the political potential of stories and narrative as 'iconoclastic tool[s] of persuasion for legal and social change'. ${ }^{23}$ Counter-narratives are increasingly strategically deployed in an attempt to challenge and expose the unacknowledged 'stories, narratives, myths and symbols' ${ }^{24}$ that construct the social and legal world. These outsider stories, told as a means of subverting or shattering complacency, expose the perspective and partiality of the storyteller:

'From the pleader's tales unravelled in Medieval Chancery and equity courts... to contemporary law review releases, stories are part of a legal tradition . . . [yet] for years, no one called them stories; they called them "truth", 25

Put simply, 'storytelling ... is never innocent. If you listen with attention to a story well told, you are implicated by and in it'. ${ }^{26}$ As storyteller and audience entwine,

19. I Durst 'Valuing women storytellers: what they talk about when they talk about law' (1999) 11 Yale JL \& Feminism 245 at 267.

20. R Delgado 'Storytelling for oppositionists and others: a plea for narrative' (1988) 87 Mich L Rev 2411 at 2414.

21. R West 'Narrative, responsibility and death' in R West Narrative, Authority, and Law (Ann Arbor: University of Michigan Press, 1993) p 419 at p 425.

22. JB Baron 'The many promises of storytelling in law: an essay review of Narrative and the Legal Discourse: A Reader in Storytelling and the Law' (1991) 23(1) Rutgers LJ 79 at 79. See, further, by way of introduction to the extensive and varied literature in this area, papers from recent symposia on law and literature: 'The power of stories: intersections of law, literature and culture' and 'The failure of the words and the rise of law and literature' (published in (2006) Texas Wesleyan Law Review 1 at 1-495 and (2005) Cardozo Law Review 2217 at 2217-2512, respectively).

23. S Winter 'The cognitive dimension of the agony between legal power and narrative meaning' (1989) 87 Mich L Rev 2225 at 2228.

24. R Delgado 'Shadowboxing: an essay on power' (1992) 77 Cornell L Rev 813 at 818.

25. L Martin-Bowen 'Words from a teller of tales: can storytelling play an effective role in feminist jurisprudence?' (1997) 66 Uni Missouri-Kansas City L Rev 95 at 109.

26. $\mathrm{P}$ Brooks 'The law as narrative and rhetoric' in P Brooks and P Gewirtz (eds) Law's Stories: Narrative and Rhetoric in the Law (New Haven: Yale University Press, 1996) p 14 at p 16. 
caught together under the story's spell, the beginnings of another story start to emerge and the storytelling continues.

So viewed, the growing collection of tales about the woman judge, told predominantly (but not exclusively) among legal academics, is perhaps unsurprising. While individually the tales might have an air of the apocryphal, together they make thoughtprovoking and sobering reading. A happy ending to the woman judge's story traditionally understood as one where everyone lives happily ever after is, it seems, some way off. Although the judiciary no longer performs 'intellectual somersaults' ${ }^{27}$ in order to keep women out, the climate toward 'outsider judges' remains somewhat 'chilly': ${ }^{28}$ 'by their anatomy, their skin pigmentation, or their accent these outsiders are brandished as biased, not to be trusted as judges and not to be accepted as members of the judicial community'. ${ }^{29}$ The experience of the woman judge is still often one of isolation, mistrust and antagonism. Moreover, as seen below, despite significant differences in the time zones, cultures, jurisdictions and centuries forming the backdrop to the tales, these themes remain constant.

Compare, for example, the ongoing campaign by the right-wing self-styled 'alternative women's group' REAL women of Canada against the 'feminist take-over' of the Canadian judicial system, ${ }^{30}$ with the harassment and criticism of Elizabeth ButlerSloss by members of the 'Fathers 4 Justice' campaign in the UK. ${ }^{31}$ Or the similarities between the recent allegations of bias made against Judge Florence Mumba sitting in the International Criminal Tribunal for the former Yugoslavia (ICTY) with the attempt to disqualify Judge Constance Baker Motley from a US employment tribunal 30 years earlier. ${ }^{32}$ Consider also the attempts to remove Bertha Wilson from the Canadian Supreme Court following her seminal speech in 1990 'Will Women Judges Really Make a Difference?' - her tentative questioning as to the possibility of judicial neutrality apparently enough to reveal her (at least to some) as 'a feminist judge who had violated her own judicial oath of impartiality and [who] was accordingly incapacitated from the execution of her judicial duties' ${ }^{33}$ - alongside Melanie Phillips' reaction to Brenda Hale's appointment to the House of Lords in October 2004:

'For despite the fact that she denied she was a hard-line feminist - "a soft-line feminist" is the most she would admit to - the fact is that she is the most ideological, politically correct judge ever to have been appointed to the highest court in the jurisdiction. As such, she will be bringing this destructive perspective

27. H Kennedy Eve was Framed - Women and British Justice (London: Chatto \& Windus, 1992) p 56.

28. C Backhouse 'The chilly climate for women judges: reflections on the backlash from the Ewanchuck Case' (2003) 15 Can J Women and Law 167.

29. C L'Heureux-Dubé 'Outsiders on the bench: the continuing struggle for equality' (2001) Wis Women's LJ 15 at 28.

30. REAL Women of Canada 'The feminist canaries are singing again' (2000) XIX(3) REALity, available at http://www.realwomenca.com/newsletter/2000_May_Jun/article_1.html. More information about REAL (Realistic, Equal, Active, for Life) Women of Canada, including position papers, press releases and past copies of their newsletter REALity is available at http:/ /www.realwomenca.com/index.html.

31. C Dyer 'Butler-Sloss criticises fathers group' The Guardian 10 November 2004; J Elliott and A Taher 'Fathers "terrorise" lawyers' Sunday Times 21 November 2004.

32. See below nn 78 and 76 respectively and surrounding text.

33. E Anderson Judging Bertha Wilson (Toronto: University of Toronto Press, 2002) p xiii. 
to bear upon binding legal decisions over some of the most difficult and contentious issues around. ${ }^{34}$

Nor do longevity or proficiency necessarily provide any protection or respite. Bertha Wilson, the first woman to sit as a Canadian Supreme Court judge, was considered as a feminist throughout her career despite her emphatic and constant rejection of the label - a moniker no doubt coined in response to criticisms rather than endorsements of her judicial approach. ${ }^{35}$ Similarly, Claire L'Heureux-Dubé, Brenda Hale and Elizabeth Butler-Sloss have all had their personal lives subject to inappropriate levels of scrutiny by the press and others as a direct result of their judicial position. ${ }^{36}$ Moreover, neither does the presence of sisterly companions seem to make much of a difference. In fact, it can sometimes make things worse - see, for example, the 'feminist canaries' jibes by REAL women of Canada:

'In times long past, miners sent canaries down into the mines to determine whether the air was safe to breathe. The canaries would sing loudly as they were lowered down the shaft and if the canary died, it indicated the presence of lethal gas and the miners would refuse to enter the mine. Today, we also have our own singing canaries, only the singing canaries of today are feminists, who instead of letting us know all is well, do quite the opposite. Whenever they start singing, we know we're headed for trouble. ${ }^{37}$

In short, while the exclusion of outsider judges nowadays is perhaps more subtle, it is no less invidious or ubiquitous. Consider, for example, the series of events that led to the jailing of Diane Fingleton in June 2003 to all intents and purposes for sending an angry email to a senior colleague whose behaviour she thought was 'disloyal' and 'disruptive':

'It did not help that the colleague, a man, [had] always thought Fingleton's appointment, by the Beattie Government, as Queensland's first woman chief magistrate in July 1999, an "appalling" choice. He used her email to accuse her of "threatening behaviour". This translated, eventually, into "retaliation against a witness", a charge put into law to deal with organised crime. Instead, it destroyed Diane Fingleton . . . the Queensland Beattie Labor Government, which appointed her [failed] to lift a finger to save her when the "old boys' club" of the Queensland magistracy closed ranks. ${ }^{38}$

However, although many are likely to agree that Diane Fingleton was 'a victim of patriarchy and bigotry' and maybe even that what happened to her 'could only have

34. M Phillips 'The judicial sister' Daily Mail 13 November 2003.

35. Anderson, above n 33, p 197.

36. See, eg, J Tibbetts 'Alberta judge's remarks shake legal community: suggests Supreme Court Justice to blame for male suicide rate The Gazette 27 February 271999 (on Claire L'Heureux-Dubé); Q Letts 'She smiled disdainfully at some other poor wretch' Daily Mail 19 November 2003 and G Levy 'Architect of a marriage wrecking measure' Daily Mail 26 April 1996 (on Brenda Hale); and J Lisners 'Cleveland judge sex scandal' News of the World 17 July 1988, available at http://www.fathercare.org/bs.htm (on Elizabeth Butler-Sloss).

37. REAL Women of Canada, above $\mathrm{n} 30$.

38. A Ramsey 'Swimming upstream and against spite' Sydney Morning Herald 2 February 2005. 
happened to a woman', ${ }^{39}$ at the same time, they might also argue that, like the narratives of fairy tales, her story seems almost too incredible to be true $;^{40}$ that it is, at best, the unique result of a combination of extreme circumstances and volatile personalities and, at worst, an unfortunate exception.

In fact, this is how many of these stories are viewed. They are downplayed or dismissed as outdated or exceptional, as curiosities shaped by and dependent on the personalities involved..$^{41}$ Their plots, as predictable and as malleable as those of fairy tales, similarly vary according to (among other things) the political preferences and historical, geographical or cultural location of teller and/or listener, and allow us to confine them to another time or place. Moreover, as jurisprudential fairy tales, the characters and narratives of the woman judge's story akin to glass slippers or giant beanstalks lend them an air of unreality and subverts their authenticity: hence, our ability to dismiss them. Moreover, as with fairy tales, there comes a time when paying too much - or indeed any - attention to these stories begins to seem 'slightly shameful . . . the taste for them reveal[ing a] lack of intellectual - and possibly moral - fibre ${ }^{42}$ or at the very least academic rigour. We must put them away, like other childhood fancies, so as to avoid any recollection of or association with old myths women have 'struggled to put behind' them, ${ }^{43}$ in order to enable those 'who are successful [to] listen to the siren call that, having succeeded in a male world, they are exceptional and... bask in the belief that they are truly blessed amongst women'. ${ }^{44}$

And yet, to stay with the story of a fairy tale is to misunderstand their purpose. Told well, these stories not only allow us to walk in the shoes of others - to acknowledge "the real battles that took place to get women where they are today, ${ }^{45}$ - but also, by throwing light onto new ways forward, they challenge complacency and the delusion 'that just because some things have changed, the struggle for equality is over' ${ }^{46}$ So viewed, it is not the story of a fairy tale itself that is important, but rather where that story takes us; the extent to which it offers 'the possibility of change, far beyond the boundaries of their improbable plots or fantastically illustrated pages' and opens windows onto previously unimaginable ways forward. ${ }^{47}$

39. Hunter, above $\mathrm{n} 7$, at 145 ; See also L Willis 'Fingleton to appeal jail sentence' The World Today Report 5 June 2003 and P Wilmouth 'A life at law turned inside out' The Age 25 September 2005.

40. On the fantastic narratives of fairy tales - described by Angela Carter as 'a story where one king goes to another king to borrow a cup of sugar' (M Warner 'Afterword' in Carter, above n 10, p 447 at p 449) - see further Warner, above n 9; M Tatar 'Introduction' in M Tatar (ed) The Annotated Classic Fairy Tales (New York: WW Norton and Company, 2003).

41. H Kennedy 'Foreword' in McGlynn, above $n$ 1, p vi. See, eg, Bertha Wilson's deliberate and 'emphatic' distancing of herself from feminist 'rants' ( $p$ 223) in her official biography (Anderson, above n 33 p 136) and criticism of this by Clare McGlynn in 'Ellen Anderson, Judging Bertha Wilson - Law as Large as Life' (2003) 11 Fem LS 307 (book review).

42. Warner, above $\mathrm{n} 9$, p xiii

43. S Day O'Connor 'Portia's progress' (1991) 66 NYU L Rev 1546 at 1557 and 1553.

44. Kennedy, above $\mathrm{n} 41, \mathrm{p}$ vi

45. S Day O'Connor 'The majesty of the law' interview for Online News Hour 9 June 2003.

46. Hale, above n $15, \mathrm{p} 135$.

47. Warner, above n 9 , p xii. 


\section{DESPERATELY SEEKING JUDICIAL DIVERSITY}

Did you hear the one about the Lord Chief Justice who, in 1992, believed that the 'present imbalance between male and female, white and black in the judiciary' would be remedied within 5 years following 'substantial appointments from both groups'? ${ }^{48}$ Or about the Lord Chancellor who promised 13 years later 'to boldly go where no Lord Chancellor has gone before' in order to ensure that 'in five years' time . . . every under-represented group [is] applying [to join the judiciary] in proportion to its presence in the pool. At every level. In our tribunals and in our courts. Progressing from post to post, according to ability. Regardless of gender, race, disability, sexual orientation, religion or age' ${ }^{49}$

Ever since John Griffith back in 1977 identified the judiciary in England and Wales as a largely homogenous group, possessing 'a unifying attitude of mind, a political position, which is primarily concerned to protect and conserve certain values and institutions', 50 the class, age, education, sex and race of the judiciary have been subject to vigorous scrutiny. ${ }^{51}$ To date, concerns about the lack of diversity within this group have largely (but not exclusively) focused on the extent to which the judicial appointments process has allowed this uniform group to 'self-perpetuate'. ${ }^{52}$

Despite some tentative steps toward judicial diversity in the early $1990 \mathrm{~s},{ }^{53}$ it was not until appointment of Lord Irvine as Lord Chancellor after the Labour election victory in 1997 that radical judicial reform appeared to be a real possibility. After all, Derry Irvine himself had, 5 years earlier, described the arrangements for the appointment of judges and the composition of the judiciary as 'outdated, secretive and elitist'. ${ }^{4}$ Yet, by April 1998, after just 1 year in office, he had been persuaded that the arrangements - although in need of some 'improvement' - were 'basically sound'. ${ }^{55}$ Nevertheless, during the late 1990 s, he commissioned a number of research projects exploring problems and potential of diversity within the judicial and legal

48. Lord Taylor The Judiciary in the Nineties, Richard Dimbleby Lecture (1992) at 9.

49. Lord Falconer Increasing Judicial Diversity: The Next Steps (2 November 2005), available at http://www.dca.gov.uk/speeches/2005/lc021105.htm.

50. JAG Griffith The Politics of the Judiciary (London: Fontana Press, 5th edn, 1997) p 7.

51. See, generally, U Schultz and G Shaw (eds) Women in the World's Legal Professions (Oxford: Hart Publishing, 2003) p 401; D Nicolson 'Demography, discrimination and diversity: a new dawn for the British legal profession?' (2005) 12(2) International Journal of the Legal Profession 201; C Thomas Judicial Diversity in the UK and Other Jurisdictions - A Review of Research, Policies and Practices (London: Commission for Judicial Appointments, 2005) (UK); Thornton, above n 14 (Australia); FM Kay and J Brockman 'Barriers to gender equality in the Canadian legal establishment' (2000) 8 Fem LS 169 (Canada); B Kruse 'Luck and politics: judicial selection methods and their effect on women on the bench' (2001) 16 Wis Women's LJ 67 and B Simon 'The under-representation of women on the Court of Appeals for the Federal Court' (2001) 16 Wis Women's LJ 113 (USA).

52. Griffith, above $\mathrm{n} 50, \mathrm{p} 22$.

53. Judicial Appointments in England and Wales - The Appointment of Lawyers to the Professional Judiciary - Equality of Opportunity and Promoting Diversity (London: Lord Chancellor's Department, October 2001).

54. Lord Irvine 'Setting new bench marks The Guardian 4 March 1992.

55. Lord Irvine, Speech to the 1998 Women Lawyer Conference, 25 April 1998. 
profession, ${ }^{56}$ and introduced a number of innovations aimed at demystifying the judicial appointments process including work shadowing schemes and the production of annual reports detailing the progress made toward increased diversity. In March 2001, the Commission for Judicial Appointments was established to investigate complaints independently and to review the appointments processes for judges and QCs. ${ }^{57}$ However, by 2003, having spent the last 6 years urging the under-represented 'don't be shy; apply', ${ }^{58}$ Irvine's reforming tendencies seemed to have stalled. Echoing Lord Hailsham 20 years earlier, in April 2003 he stated to the Select Committee on the Lord Chancellor's Department that he believed the 'existing system... has been brought to as good a state as it can be'. ${ }^{59}$

Enter Charlie Falconer: a Lord Chancellor with a mission, ready to go 'boldly' in his pursuit of judicial reform. ${ }^{60}$ He got off to a flying start. In July 2003, the re-named Department for Constitutional Affairs published the consultation paper Constitutional Reform: A New Way of Appointing Judges as part of the Labour Government's wider programme of constitutional reform, which sought views on the form and responsibilities of an independent Judicial Appointments Commission. ${ }^{61}$ The following year, in his address to the Labour Party Annual Conference, he promised to deliver "real change':

'We are going to take steps to increase diversity in the judiciary. Judges must be and will continue to be appointed on merit. But it can't be lack of merit, can it, that means it's taken until this Labour government to appoint the first-ever woman judge in the House of Lords? Or . . f for the first-ever member of an ethnic minority to become a High Court judge?' ${ }^{62}$

A month later, in October 2004, the consultation paper, Increasing Diversity in the Judiciary, was published, examining both the reasons for the ongoing lack of judicial diversity and seeking feedback on a number of options for increasing diversity. ${ }^{63}$ Since then, the Falconer-era has brought with it a number of changes, including allowing for a reduction in the time spent as advocate before qualifying for judicial appointment, opportunities for job sharing, career breaks and a mentoring scheme. ${ }^{64}$ In March

56. Sir Leonard Peach An Independent Scrutiny of the Appointment Processes of Judges and Queen's Counsel in England and Wales (London: Lord Chancellor's Department, 1999); K Malleson and F Banda Factors Affecting the Decision to Apply for Silk and Judicial Office Lord Chancellor's Department Research Series 2/00 (London: Lord Chancellor's Department, 2000).

57. Replaced by Judicial Appointments and Conduct Ombudsman in April 2006.

58. See, eg, Lord Irvine, Speech to the Association of Women Barristers, 11 February 1998; Speech to the Ethnic Minority Lawyers' Conference, March 1999; Speech to the IBA World Women Lawyers Conference, 1 March 2001; Speech to the Association of Women Solicitors, 23 March 2001.

59. Lord Irvine, Evidence to the Select Committee on the Lord Chancellor's Department (2 April 2003) para 72; Leader 'Good judgment - Lord Irvine is right to think again' The Guardian 4 April 2003.

60. Lord Falconer, above $n 49$.

61. Department of Constitutional Affairs Constitutional Reform: A New Way of Appointing Judges (CP 10/03, July 2003) and Summary of Responses to the Consultation Paper (January 2004).

62. Charlie Falconer 'Opening up our institutions for the future', Speech to the Labour Party Conference 29 September 2004.

63. Department of Constitutional Affairs Increasing Diversity in the Judiciary (CP 25/04, October 2004) and Responses to DCA Consultation Paper (March 2005).

64. Lord Falconer, above n 49. 
2005, the Lord Chancellor introduced the judicial diversity programme, which seeks to build and expand these developments, focusing on three main areas: encouraging applications and raising awareness; removing barriers to appointments; and meeting the needs of a more diverse judiciary. ${ }^{65}$ On 3 April 2006, key parts of the Constitutional Reform Act 2005 came into force, including the legislative provisions establishing an independent Judicial Appointments Commission designed to remedy what Sir Colin Campbell described 5 years earlier as the 'serious and chronic problems in the old system of appointing judges ${ }^{66}$ by ensuring that 'judicial appointments are fair, transparent and made on merit' ${ }^{67}$

And yet, while the judiciary in England and Wales is the most diverse it has ever been, with almost twice as many women and people from ethnic minority groups working in and being appointed to the judiciary than there were 10 years ago, there is, as the Lord Chancellor acknowledges, 'still more to do if we are to achieve a judiciary that better reflects the society it serves' ${ }^{68}$ On current figures, we are in danger of having what Baroness Hale of Richmond describes as a 'pale male judiciary' for some time yet. ${ }^{69}$ Although just over $25 \%$ in the judiciary as a whole is female, women make up less than $11 \%$ of full-time judges. Moreover, just 11 women sit in the High Court and above alongside 94 men; put another way just under $95 \%$ of the senior judiciary is male. ${ }^{70}$ Following the retirement of Dame Elizabeth ButlerSloss as President of the Family Division, none of the Heads of Division is female. Judges from a non-white ethnic minority background fare even worse. Linda Dobbs' hope that her appointment to the High Court in 2004 'would be the first of many' has not yet been realised..$^{71}$ Non-white ethnic minority groups remain significantly underrepresented in both the senior judiciary and the judiciary as a whole, comprising just $0.6 \%$ and $3 \%$, respectively. ${ }^{72}$

65. See further http://www.dca.gov.uk/judicial/diversity/index.htm.

66. C Campbell, Evidence to the Constitutional Affairs Committee (11 November 2003).

67. Baroness Prashar in Department of Constitutional Affairs Press Notice 'Constitutional reforms come into force' 23 January 2006. On the new Judicial Appointment Commission see further Lord Falconer 'Implementation of the Constitutional Reform Act 2005' Written Ministerial Statement (January 2006) and the official website at http://www.judicialappointments.gov.uk. Unlike the Judicial Appointments Commission in Northern Ireland, which has a statutory duty to ensure, so far as is reasonably practicable to do so, that the judiciary reflects the community of Northern Ireland (Justice (Northern Ireland) Act 2004, s 3), this Commission (like the Judicial Appointments Board for Scotland's remit to consider ways of recruiting a judiciary which is as representative as possible (http://www.judicialappointmentsscotland. gov.uk)) need only have regard to the need to encourage judicial diversity (Constitutional Reform Act 2005, s 64(1)).

68. Department of Constitutional Affairs Press Notice 'Continued increase in minority ethnic and female judicial appointments' 31 January 2006.

69. B Hale 'Making a difference? Why we need a more diverse judiciary' (2005) 56(3) NILQ 281.

70. Figures taken from the Directorate of Judicial Offices website as at 1 October 2006, available at http://www.judiciary.gov.uk/keyfacts/statistics/women.htm.

71. 'High Court gets first black judge' BBC News Website (2 September 2004), available at http://news.bbc.co.uk/1/hi/uk/3621648.stm.

72. Figures taken from the Directorate of Judicial Offices website as at 1 October 2006, available at http://www.judiciary.gov.uk/keyfacts/statistics/ethnic.htm. See, further, T Abbas Diversity in the Senior Judiciary - A Literature Review of Research on Ethnic Inequalities (London: Commission for Judicial Appointments, 2005). Although there are no official figures available in relation to other indicators of diversity, for example age, sexuality, educational 
All in all, although the Department for Constitutional Affairs' intentions have been good, the reality remains somewhat disappointing. ${ }^{73}$ A truly diverse judiciary is still some way off. Nevertheless, despite these 'dispiriting figures ... there exists a belief voiced by some of our most senior judges, that we have one of the best judiciaries in the world - if not the best: . . undoubtedly incorruptible; seriously intelligent; extraordinarily industrious; and fiercely independent' ${ }^{74}$

This is not, in and of itself, of course particularly problematic. After all, integrity, intellect, diligence and neutrality are, and should always be, among the salient hallmarks of any judge. The difficulty is that often 'these perceptions are also linked to more deep-rooted British - especially English - unconscious assumptions about who is "the best": well bred, well spoken, well educated, white males' ${ }^{75}$ The chilly judicial climate runs deeper than a simple need to even up the numbers.

\section{DIVERSITY UNCOVERED}

Incidentally, did you hear about the attempt by a New York law firm to disqualify an African-American judge from adjudicating in a sex discrimination trial because she was 'strongly identified with those who suffered discrimination in employment because of race and sex' ${ }^{76}$ Alternatively, were you aware of the judicial findings that the remarks that 'police officers do overreact, particularly when they are dealing with non-white groups' made by a black female Canadian judge gave rise to 'a reasonable apprehension of bias'? ${ }^{77} \mathrm{Or}$, similarly, the appeal of an international tribunal's decision grounded in the claim that the judge's former membership of a UN expert group on gender and, more specifically, her stated belief that rape should be

background, disability or religion, on the educational background of the senior judiciary see the Sutton Trust Briefing Note The Educational Backgrounds of the UK's Top Solicitors, Barristers and Judges (2005), available at http://www.suttontrust.com/reports/ Comparison_educational_backgrounds.pdf; on disability within the judiciary, see the Report on Progress against the DCA's Action Plan on Disability Equality and Judicial Appointment (December 2005), available at http://www.dca.gov.uk/publications/reports_reviews/ disequ_progressrep.pdf; and on the appointment of the youngest-ever magistrate, Anand Limbachia, see J Robins 'Are teenagers really mature enough to serve as magistrates' The Times 8 November 2005.

73. For a comparison with progress made worldwide see Thomas, above n 51 .

74. Hale, above, n 69, at 282. See, eg, Lord Falconer Opening of the Legal Year in Northern Ireland (5 September 2005), available at http://www.courtsni.gov.uk/NR/rdonlyres/ 8A7BEDEB-73C0-43B7-B0D1-88B88E25A248/0/p_pm_lcspeech.doc; Sir John Baker Response to the DCA Consultation Paper Constitutional Reform: A New Way of Appointing Judges (November 2003), available at http://www.dca.gov.uk/consult/jacommission/responses/ ja008.pdf; Keith Vaz MP Hansard HC Deb, vol 334, col 137, 29 June 1999.

75. Hale, above n 69 , at 282. On the perception that judges reflect a certain profile: 'male, Silk, an all round decent chap', see further Commission for Judicial Appointments Annual Report (London: Commission for Judicial Appointments, 2005), particularly, paras 3.21-3.25 and the subsequent exchange between Lord Falconer and Sir Colin Campbell published alongside it.

76. Blank v Sullivan and Cromwell 418 F Supp 1, 4 (SDNY 1975) discussed in L'HeureuxDubé, above n 29.

77. $R D S \vee R$ [1995] NSJ No 184 (SC); $R \vee R D S$ (1995) 145 NSR (2d) 284 (CA); $R \vee S(R D)$ [1997] 3 SCR 484. 
considered a war crime should have disqualified her from hearing a case on exactly that issue ? $^{78}$

The Department for Constitutional Affairs' consultation paper Increasing Diversity in the Judiciary defines diversity as: 'The presence among a group of individuals of a wide variety of backgrounds, cultures, opinions, styles, perspectives, values and beliefs' ${ }^{79}$ According to this definition, judicial diversity simply requires the presence of a miscellaneous - albeit strategic - assortment of difference or dissimilarity on the bench. And yet, at the same time, the Lord Chancellor is unwavering in his belief that judicial appointments must continue to be made on 'merit', without regard to 'irrelevant' factors such as age, disability, gender, ethnicity, marital status, political affiliation, religion or belief, sexual orientation, or gender identity. ${ }^{80}$ This promotion, on the one hand, of diversity as essential to ensure (among other things) public confidence in the judiciary while at the same time downplaying the very attributes that constitute diversity - age, disability, social and cultural background, gender, ethnicity, marital status, political affiliation, religion or belief, sexual orientation - as irrelevant seems somewhat disingenuous. Moreover, while a more diverse judiciary is a key priority both in relation to government policy and the ongoing legitimacy of the judiciary itself, the elevation of merit as the sole criterion makes the new Judicial Appointments Commission's mission to increase diversity, if not impossible, much more difficult. This is not least because the principle that judicial appointments must be made on merit seems somewhat self-fulfilling. A candidate is appointed on 'merit' when they meet the criteria of appointment, that is, the skills, abilities and personal qualities apparently required of a judge, ${ }^{81}$ without regard to their gender, ethnic origin and so on. So viewed, Lord Falconer's belief that there is no conflict between merit and diversity is, at best, somewhat optimistic and, at worse, deliberately naïve. ${ }^{82}$

However, while others have highlighted the use of merit as means of excluding outsider judges - "it is strange how this word "merit" only pops up when there is talk of changing or expanding the pool from which the judiciary are appointed"83 - or have agued for the rethinking of its traditional definition, ${ }^{84}$ my focus here is not on merit per se, but rather on the extent to which its siren call constrains the potential of diversity to transform understandings of the judge and judging. To pose a question that so far the Department for Constitutional Affairs' initiatives appear to have failed to address: what might a truly diverse judiciary and/or judge look like?

78. Prosecutor v Furundzija Case No IT-95-17/1A.

79. Increasing Diversity in the Judiciary, above n 63, p 57.

80. Lord Falconer 'Foreword' in Increasing Diversity in the Judiciary, ibid, p 8.

81. These include (at least for the time being) legal knowledge and experience, intellectual and analytical ability, sound judgment, decisiveness, communication and listening skills, authority and case management skills, integrity and independence, fairness and impartiality, understanding of people and society, maturity and sound temperament, courtesy, commitment, conscientiousness and diligence (ibid, p 57). The Judicial Appointments Commission is currently reconsidering these requirements and will publish a new set of 'considerably more succinct' requirements in due course (J Rosenberg 'So how can we judge the judges?' Daily Telegraph 20 July 2006).

82. Lord Falconer, above n 80.

83. B Hale Equality in the Judiciary: A Tale of Two Continents Tenth Pilgrim Fathers' Lecture (2003). See also the Commission for Judicial Appointments Annual Report (London: Commission for Judicial Appointments, 2005) pp 22-29 and Kennedy, above n 27, pp 60-62.

84. K Malleson 'Rethinking the merit principle in judicial selection' (2006) 33(10) J Law and Soc 126 and 'Justifying gender equality on the bench: why difference won't do' (2003) 11 Fem LS 1 at 16. 
The starting point is diversity itself. Despite the Department for Constitutional Affairs' pragmatic acceptance of the importance of difference within any given group of individuals, the politics of diversity require more than simply tolerating the presence of varied perspectives and distinctive backgrounds - after all, 'toleration implies disapproval or dislike. We do not tolerate things we like or endorse' ${ }^{85}$ Rather, diversity compels us to create a space in which difference is celebrated and valued on its own terms.$^{86}$ Diversity is not about letting people in but about letting go. It challenges the complacency and normative superiority of the status quo. In the quest for diversity, "majority groups are not entitled to retain more cultural status and recognition than others; they must therefore let go of some of their privilege, however painful such a letting go may feel' ${ }^{87}$ In so doing, diversity requires us 'to look away from that which stands out as different in order to be able to evaluate the mainstream, the common and the "normal" , 88 to look not at the unusual but instead at the mundane or taken for granted and, in so doing, to embrace difference not as 'intrinsic in the "different" person, but rather the product of comparison" ${ }^{89}$

So understood, calls for a more diverse judiciary bring with them an opportunity for reflection; the chance to move beyond strategies which seek simply to ensure the presence of outsider judges within the confines of traditional understandings of the judge and judging; a chance to explore the transformative potential of difference and radically rethink what it is we want from our judiciary. It is perhaps time to let go of our instinctive understandings of the judge and judging - however painful that might be - and listen to the subtext of the jurisprudential fairy tales.

Take, for example, the tales of Justices Sparks, Motley and Pillay. These tales spanning four decades, three jurisdictions and two continents have - at least - one common theme: the judges' distinguishing characteristics - that is, their race and sex - allowed for a reasonable possibility that they would (or had) over-identify with those before them. And yet, while the plotline of their stories - of yet another, ultimately unfounded, bias claim against an outsider judge - gets our attention, it can also distract us from exploring what is really going on. Put another way, to allow ourselves to become embattled by feelings of (albeit perhaps righteous) indignation on hearing these tales - to get 'bogged down' in the story - risks constraining their fairy tale potential as catalysts for disruption. In fact, what these tales reveal is the extent to which the presence of diversity throws a spotlight onto conventional understandings of the judge and judging, challenging the listener to leave the security of the familiar and to embark on new adjudicative adventures.

In many ways, perhaps, the protagonists in these and other tales are easy targets. They stand out. Their 'difference' acts as an irritant, undermining the 'white male paradigm of what it means to be a judge ${ }^{90}$ and revealing particular understandings of the judge and judging which, although often dismissed as fiction, continue to have

85. J Weeks 'Rediscovering values' in J Squires (ed) Principled Positions: Postmodernism and the Rediscovery of Value (London: Lawrence and Wishart, 1993) p 189 at p 206.

86. D Cooper Challenging Diversity: Rethinking Equality and the Value of Difference (Cambridge: Cambridge University Press, 2004) p 7.

87. Ibid, $\mathrm{p} 35$.

88. Ibid, pp 193-194.

89. M Minow 'Making all the difference: three lessons in equality, neutrality, and tolerance' (1989-1990) 39 De Paul L Rev 1 at 3.

90. L'Heureux-Dubé, above n 29, at 28. 
operative effects. ${ }^{91}$ Their unavoidable deviance from the aesthetic norm troubles traditional understandings of legal authority and ensures an immediate confirmation of bias. As a result, their judgments, branded with the stigmata of difference, are always open to question. ${ }^{92}$ The finding by both the Nova Scotia Supreme Court (Trial Division) and Court of Appeal of a reasonable apprehension of bias in the remarks of Justice Sparks in $R \vee S(R D)^{93}$ - reflecting 'an emerging pattern whereby women who are beginning to "make it" in the higher echelons of legal bureaucracies are constructed as presumptively partisan' - is a case in point, ${ }^{94}$ when difference speaks distance and authority give way to an, albeit rebuttable, presumption of 'incompetency, inadequacy and unsuitability, ${ }^{95}$

And yet, of course, the recognition of bias and impartiality in judgment must cut both ways: "the issue of "bias" in judgment actually boomerangs. The question becomes whether those who would assume a woman is favourably biased toward other women are themselves adversely biased toward women'. ${ }^{96}$ Put simply, the outsider judge challenges the notion of judicial impartiality as 'the view from nowhere'. After all, as Judge Motley explained when denying the defendant's attempt to prevent her from judging a sex discrimination case because, as a black woman, she 'would identify with those who had experienced sex or race discrimination' : "if background or sex or race of each judge were, by definition, sufficient grounds for removal, no judge . . . could hear this case, or many others, by virtue of the fact that all of them were attorneys, of a sex'.$^{98}$

In fact, what these challenges to the authority of the outsider judge reveal - that is, where the stories of the jurisprudential fairy tales take us - is not inappropriate identification, 'bigotry, prejudice, or intolerance' (what Patricia Cain terms 'bad' bias) but rather the extent to which we need a judge who embodies the previously disparaged traits of the outsider; ${ }^{99}$ a judge with so-called 'good bias', ${ }^{100}$ that is, preferences and affections that 'facilitate the gathering of knowledge . . . and lead us to the truth';101 a judge with the 'special ability to listen with connection before engaging in the separation that accompanies judgment' ${ }^{\prime 02}$ and who is willing to walk

91. E Rackley 'Representations of the (woman) judge: Hercules, the Little Mermaid and the vain and naked Emperor' (2002) 22 LS 602 at 618.

92. Berns, above n 13, p 33 .

93. See above $\mathrm{n} 77$.

94. R Devlin 'We can't go on together with suspicious minds: judicial bias and racialized perspective in $R v R D S$ ' (1995) 18 Dalhousie LJ 408 at 443, n 178. The lower courts' decisions were subsequently overturned by a majority of the Canadian Supreme Court in $R v S(R D)$ [1997] 3 SCR 484; see further collection of case comments in (1998) 10 Canadian Journal of Women and Law 159-212.

95. Judge O'Sullivan quoted in Thornton, above n 14, p 208.

96. Minow, above $\mathrm{n} 89$, at 7 .

97. Ibid, at 6 .

98. Blank $v$ Sullivan and Cromwell, above $\mathrm{n} 76, \mathrm{p} 4$.

99. P Cain 'Good and bad bias: a comment on feminist theory and judging' (1988) $61 \mathrm{~S} \mathrm{Cal}$ L Rev 1945 at 1946.

100. Ibid.

101. LM Antony 'Quine as a feminist: the radical import of naturalised epistemology' in LM Antony and C Witt (eds) A Mind of One's Own: Feminist Essays on Reason and Objectivity (Boulder: Westview Press, 1993) p 185 at p 215.

102. Cain, above n 99, at 1954. 
in the shoes of others; a judge like, for example, Navanethem Pillay in the tale of Akayesu. ${ }^{103}$

Jean Paul Akayesu was Bourgmestre of the Taba commune during the 1994 Rwandan Civil War. In 1998, the International Criminal Tribunal for Rwanda (ICTR) found him guilty of ordering, instigating, aiding and abetting crimes against humanity and acts of genocide against the Tutsi people. Of particular interest is the tribunal's innovative finding, alongside identifying rape as a crime against humanity, that:

'rape and sexual violence... constitute genocide in the same way as any other act as long as they were committed with the specific intent to destroy, in whole or in part, a particular group targeted as such . . . Sexual violence was an integral part of the process of targeting Tutsi women and specifically contributing to their destruction and to the destruction of the Tutsi group as a whole.' ${ }^{104}$

Akayesu subsequently appealed against his conviction on a number of grounds including allegations of bias against Justice Pillay and the other judges. Justice Pillay had, Akayesu argued:

'[gone] on a public speaking tour before the defence had begun. Without commenting on individual testimony, she stated publicly on 12 November 1997, on a radio program on the Canadian Broadcasting Corporation (CBC) that victims of sexual violence in Rwanda don't dare use explicit sexual words . . . She also spoke of 200,000 victims of sexual violence and a political strategy of sexual violence none of which was proven properly before the Court. She made similar comments in at least one magazine and at a colloquium at York University, Toronto. ${ }^{105}$

This, along with the rest of his grounds for appeal, was rejected. However, while Akayesu's allegations of so-called 'bad' bias get our attention it is not the end of the story. My purpose in re-telling Pillay's tale is not simply to focus on what she said or did outside the courtroom - her public speaking tour or general comments about victims of sexual violence - but also to explore her actions inside the courtroom, that is, the extent to which her connection with the victims' testimony - her 'good' bias - affected the original indictment and act of judgment. Put another way, there is more going on here in terms of Pillay's understanding of judging and judgment than might, at first, be apparent.

Indeed, far from evidencing bad judgment, the decision in Akayesu has since 'resulted in the most progressive case law on gender ever pronounced by an international judicial body'. ${ }^{106}$ What is more, there is no doubt that Pillay's empathetic

103. Prosecutor v Akayesu Case No ICTR-96-4-T (2 September 1998); ICTR-96-4-A (1 June 2001).

104. ICTR-96-4-T, para 73.1

105. ICTR-96-4-A, Annex B, Third Ground of Appeal Biased and Partisan Tribunal at (i)

106. $K$ Askin 'Sexual violence in decisions and indictments of the Yugoslav and Rwandan tribunals: current status' (1999) Am J Int Law 97 at 100. See also Statement by Justice Louse Arbour, Press Release (ICTY Doc. CC/PIU/342-E, 4 September 1998). On the Akayesu legacy in the ICTR, ICTY and the International Criminal Court, see further K Askin 'Gender crimes jurisprudence in the ICTR' (2005) 3 J Int Criminal Justice 1007; B Nowrojee " "Your justice is too slow": will the ICTR fail Rwanda's rape victims?', United Nations Research Institute for Social Development Occasional Paper Gender Policy 10 (2005), available at http://www. unrisd.org/80256B3C005BCCF9/(httpPublications)/56FE32D5C0F6DCE9C125710F0045D89F? OpenDocument; and N Pillay 'The advancement of women's rights' Occasional Paper No 16 (Centre for Human Rights, University of Pretoria, September 2002). 
connection with the prosecution witnesses has changed the course of women's jurisprudence in the international institutions. ${ }^{107}$ Eschewing the notion of judicial impartiality as requiring a detached and disengaged 'blank slate', ${ }^{108}$ she infused her justice with empathy and care, recognising impartiality not as 'some stance above the fray, but [rather] the characteristic of judgments made by taking into account the perspectives of others in the judging community'. ${ }^{109}$ In so doing, she shaped the tribunal's multi-dimensional understanding of rape as both a serious and coercive invasion of a woman's physical and mental integrity and also a means through which to destroy a group. She not only gave the women involved a voice to articulate what had happened to them, but also allowed her fellow tribunal members and others to see the bigger picture. Put simply, her recognition of the context of the crimes, underlining the importance of having judges sympathetic to gender issues within these institutions' 110 - her use of 'good' bias - started the process by which the tribunal not only developed their understanding of rape and sexual violence as a personal crime but also considered the global consequences of Akayesu's actions: genocide.

So viewed, perhaps Bertha Wilson has a point. Maybe:

'women view the world and what goes on in it from a different perspective from men; and . . . women judges, by bringing that perspective to bear on the cases they hear, can play a major role in introducing judicial neutrality and impartiality into the justice system. ${ }^{111}$

However, this is not to suggest that all women necessarily think, speak or judge in the same way, that there is somehow an essential female perspective and/or voice to suggest that there are echoes of Gilligan's different voice in their narratives

107. Askin 'Gender crimes jurisprudence in the ICTR', ibid, at 1009. Interestingly, the original indictment against Akayesu did not originally include charges of sexual violence in this case; the virtually all-male group of investigators did not find enough evidence for such crimes. However, after the trial had begun sufficient evidence began to emerge as, encouraged by Pillay (the only female judge present), the witnesses began to talk of rape and other acts of sexual violence. The trial was subsequently adjourned. Following more detailed investigations, the indictment against Akayesu was amended by Chief Prosecutor, Louise Arbour, and when the trial resumed, a year later, extensive witness testimonies detailing the use of rape and sexual violence were introduced. On the role of women's pressure groups in this case see Askin 'Sexual violence in decisions and indictments of the Yugoslav and Rwandan tribunals: current status', ibid, at 106; R Copelon 'Gender crimes as war crimes: integrating crimes against women into international criminal law' (2000) 46 McGill LJ 217; L Chappell 'Women, gender and international institutions: exploring new opportunities at the International Criminal Court' (2003) 22(1) Policy, Organisation and Society 3 at 10-12; T Rosenberg 'New punishment for an ancient crime' New York Times 5 April 1998.

108. C L'Heureux-Dubé 'Making a difference: the pursuit of a compassionate justice' Notes for an Address to the International Bar Association, Amsterdam, Netherlands, IBA Joint Session on 'Women on the Bench', 20 September 2000, on file with author.

109. J Nedelsky 'Embodied diversity and the challenges to law' (1997) 42 McGill LJ 91 at 107, citing Hannah Arendt, in R Beiner (ed) Lectures on Kant's Political Philosophy (Chicago: University of Chicago Press, 1982).

110. Chappell, above n 107, at 12 .

111. B Wilson 'Will women judges really make a difference?' (1990) 28 Os HLJ 507 at 515. See, eg, the judgments of Brenda Hale in Parkinson v St James and Seacroft University Hospital NHS Trust [2001] QB 266, discussed in E Rackley 'Difference in the House of Lords' (2006) 15(2) Social and Legal Studies 163 or Bertha Wilson in $R v$ Morgentaler [1988] 1 SCR 30, discussed in E Halka 'Madam Justice Bertha Wilson: a 'different voice' in the Supreme Court of Canada' (1996) 35(1) Alberta L Rev 242. 
(although there may be similarities in tone). ${ }^{112}$ My point is not that Pillay - or indeed any other female judges referred to here - acted as they did because they are women (although, of course, there may be some correlation). Nor is it to suggest that all women or outsider judges experience the difficulties described here. Rather my point is this: it is because she is woman that we both look for, and find, difference. Put another way, the difference it makes is its facility to point the way towards new and/ or previously overlooked conceptions of the judge and judging. Beyond its fairy tale narrative, Pillay's story reveals the extent to which difference can act as a catalyst for disruption. Subverting the legal monotony, it advances our understanding of the adjudicative process by highlighting aspects not normally perceived as such - for example, the importance of 'listening with connection' and contextualisation - while reworking traditional notions of the judge and judging. The negative becomes a positive. The actions of Pillay which inspired the fairy tale plot, rather than evidencing bad judgment, are instead seen to reveal the particularity of conventional understandings of adjudication; the 'moral' or purpose of her story highlighting not only the limiting effects of equating judicial impartiality with the Herculean denial of perspective - of believing all bias to be 'bad' - but also the importance of incorporating experience and perspective of previously under-represented voices on the bench.

To this end, the stories of the woman judge provide a means of destabilising takenfor-granted assumptions about the judge and judging. Understood as fairy tales, they throw a light onto previously overlooked or unimaginable adjudicative techniques and approaches and hitherto hidden aspects of legal decision making. They reveal that which is often denied in more traditional accounts of adjudication: that who the judge is matters. It matters both in terms of 'the kind of story ultimately told, and for the way that story reaches the law and the law reaches that story'. ${ }^{113}$ Put another way, the stories of isolation, hostility and suspicion told throughout this paper stem from an instinctive yet ultimately suffocating image of the judge which, despite being perhaps more imagined than real, operates to maintain the characterisation of the 'different' judge as a dangerous outsider. So viewed, true judicial diversity (and all the benefits it brings) will only occur if we, like the Sultan, embrace the transformative potential of the meat of the tongue - of stories - as a means of interrogating the normal or mundane and thereby enabling us to move beyond difference and, in so doing, begin to imagine where diversity might take us.

\section{HAPPY ENDINGS AND NEW BEGINNINGS - CONCLUDING THOUGHTS}

\section{Remember Belva Lockwood - the student refused entry to the University of Columbia's law faculty because her presence would distract the attention of the young}

112. The extent to which women judges speak in a 'different voice' - although perhaps intuitively attractive - remains hotly disputed among both legal academics and professionals; see, eg, Malleson 'Justifying gender equality on the bench: why difference won't do', above n 84; Day O'Connor, above n 43; Wilson, above n 111; HH Kay and G Sparrow 'Workshop on judging: does gender make a difference?' (2001) 16 Wis Women's LJ 1. On the criticism of essentialism, see from the varied and wide-ranging literature, M Minow 'Foreward: justice engendered' (1987) 101 HLR 10 at 62-63; J Conaghan 'Reassessing the feminist theoretical project in law' (2000) 27(3) J Law \& Soc'y 351 at 366-368 and S Rush 'Understanding diversity' (1990) 42 Florida Law Review 1 at 20-21.

113. Berns, above n $13, \mathrm{p} 8$. 
men - she went on to become the first woman to be admitted to practise before the US Supreme Court. And the top-ranking student offered the job of legal secretary? That was Sandra Day O'Connor, the first female judge to sit on the US Supreme Court. You can't have forgotten about the female judge asked to leave the room after dinner so that her male colleagues could enjoy their port and wine in peace - that was Brenda Hale - and she refused to go. How about the various attempts to disqualify a number of female judges for bias-related reasons - because they were pregnant, a heavy smoker, black, female - well, they all eventually failed as did the attempt to introduce quotas to redress the feminisation of the French judiciary. Incidentally, Diane Fingleton has returned to the legal profession as a magistrate in Caloundra, Queensland and Navanethem Pillay is one of seven women appointed to the bench of the International Criminal Court. Finally, remember Tattersall's, the male members-only club who withdrew their invitation to a newly appointed judge on learning her sex... well, some things never change. ${ }^{114}$

In a survey for World Book Day 2006, 41\% of people surveyed said they preferred a book with a happy ending compared to just $2.2 \%$ favouring a sad one. ${ }^{115} \mathrm{~A}$ happy ending - whatever that may mean - apparently not only gives the reader a sense of satisfaction but also puts them in a good mood for the rest of the day. ${ }^{116}$ Maybe this is why one tradition of fairy tales is to represent endings as beginnings; no matter how unlikely it is in real life, at the end of a fairy tale we are able to believe, should we wish, that everyone lives happily ever after - just like the Sultana.

So where does this leave the story of the woman judge? The stories so far seem to suggest that a happy ending - traditionally understood as one where she lives happily ever after with her Herculean prince - is likely to remain elusive for some time yet. However, a fairy tale ending is perhaps closer than we might at first think. In fact, once endings become (in the tradition of fairy tales) new beginnings, the promise of living happily ever after seems somewhat tame - after all, 'if Anna and Vronsky or Scarlett and Rhett had lived happily-ever-after we would have forgotten them'. ${ }^{117}$ It is perhaps time to let go of the security of the happily ever after and instead embrace, with Scarlett O'Hara, the promising uncertainty of tomorrow. ${ }^{118}$

All in all, it seems that despite ongoing and intensive efforts at judicial diversification, equal participation - both quantitatively and qualitatively - of women (and other under-represented groups) on the bench has not come about. Of course, the judiciary is not unique in this regard. The Equal Opportunities Commission's annual exploration of women's representation in senior positions across both the public and private sector concludes that at current rates, as with the senior judiciary, it will take another 40 years for there to be equal numbers of men and women as directors of FTSE 100 companies and an incredible '200 years - another 40 elections - to achieve

114. S Parnell and C Mathewson 'Beattie sticks with Tatt's despite no-women vote' Courier Mail 27 March 2003.

115. Readers Live Happily Ever After on World Book Day (2 March 2006), available at http:// www.worldbookday.com/documents/Happy\%20Endings\%20News\%20Release.doc.

116. Ibid.

117. Ibid.

118. M Mitchell Gone with the Wind (London: Pan Books Ltd, 1974) [first published 1936] p 1011. 
an equal number of women in Parliament'. ${ }^{119}$ Their figures also suggest that while women, clearly, have made great strides toward equality since the enactment of the Sex Discrimination Act in 1975, in recent years this progress has tailed off. The representation of women in the senior judiciary is comparable, for example, to that of senior police officers (10\%) and editors of national newspapers (13\%), where 'only a few have broken through the glass ceiling ... too often the result of their exceptional strength of character and drive to achieve despite significant barriers' ${ }^{120}$ Nor is the legal profession alone in its continuing - and increasingly criticised - commitment to rigid working practises and long-hours culture. ${ }^{121}$ In fact, in a poll of over 2000 adults in October 2005, six out of ten of those asked believed it is harder for working women to balance work and family life today than it was 30 years ago: the Sex Discrimination Act 1976 has, it seems, largely delivered women a right that is neither realistic nor particularly attractive - 'the right to live like men did three decades ago'. ${ }^{122}$

Nevertheless, despite these similarities with other professions and organisations, given the significant political investment and general public support for measures seeking to ensure a more diverse judiciary, the persistent failure of these initiatives is troubling. The difficulty is that, to date, the Department for Constitutional Affairs' initiatives have operated to temper the transformative potential of difference. They have effectively sought to both establish and constrain diversity; promoting an understanding of it that is both limited and limiting - an insipid, watered-down 'diversitylight' akin to reduced-sugar soft drink alternatives - which seeks all the political gains of a more diverse bench without any of its troublesome effects. So viewed, it is then unsurprising that despite continuing proposals and, perhaps, well-meaning rhetoric seeking to endorse and encourage a more diverse judiciary, there has been little change to the judicial climate either in terms of broadening the make up of the bench or nurturing those 'outsiders' who are already there. Diversity-light does little more than scratch the surface of the bench, allowing the more invidious effects of a homogenous judicial culture and instinctive understandings of the judge and judging to continue relatively unscathed. Moreover, the failure of current government initiatives to engage directly with these intuitive - yet particular - understandings of the judge and judging not only does little to offer the newly added outsider judge protection against the chilly judicial climate - effectively abandoning them to their fairy tale fate ${ }^{123}$ - but also perpetuates and reinforces understandings of adjudication, which (like the right delivered to women by the Sex Discrimination Act 1976) are in need of reconsideration. It is, then, perhaps time to think more imaginatively about

119. Equal Opportunities Commission Sex and Power: Who Runs Britain? (Manchester: Equal Opportunities Commission, 2006) p 1. Again, women from an ethnic minority background fare even worse. For example, only two of the 127 female MPs in the UK Parliament are ethnic minority women (there are no ethnic minority women sitting in the Scottish Parliament or the National Assembly for Wales) and a mere 3.3\% of FTSE 100 company directors are from an ethnic minority group (ibid, p 3).

120. Ibid, $\mathrm{p} 2$.

121. F Gibb 'Is there a bar to having it all?' The Times 22 February 2005. On the difficulties experienced by men who seek to balance their work and family life, see further J Carvel 'Third of men drink to drown out job stress' The Guardian 8 June 2006 and R Collier 'Work-life balance: ladies only?' [2005] The Lawyer 33.

122. Equal Opportunities Commission, above n 119, p 3.

123. M Mendelson 'Forever acting alone: the absence of female collaboration in Grimms' Fairy Tales' (1997) 28(3) Children's Literature in Education 111. 
judicial diversity - to look beyond our Herculean images of the judge and judging and embrace the fairy tale promise of difference.

Properly understood, judicial diversity is not simply about ensuring that a strategic assortment of judges (or whoever) of varying ages, sex, race, class, culture and so on live 'happily ever after' - an evening up of the numbers on the bench to ensure a kind of numerical aestheticism. Nor is it about securing the resigned acceptance by the status quo of the inclusion of difference as a political necessity - albeit with the tacit assurance that nothing will really change. Merely tolerating the presence of difference within a given group does little to ensure its diverse credentials. Rather, diversity requires the usual to be transformed by the remarkable, and the extraordinary to become the norm. It is as much about looking at that which difference is different to - the everyday or mundane - as it is about looking for difference itself. So viewed, judicial diversity ultimately subverts that which it is said to reinforce; a truly diverse judiciary is one that utilises the presence of difference on the bench as a means of exploring aspects of judging often overlooked in conventional accounts of adjudication; that begins to re-imagine what it is we want from our judiciary and what it means to be a judge.

To this end the stories of the woman judge - told here as fairy tales - can be seen to offer a window onto previously unconsidered or ignored adjudicative landscapes and techniques. While their narratives of inexplicable exclusion, ongoing hostility and even downright misogyny get our attention, their purpose goes beyond the fantastic elements of their storylines. Their stories expose our continuing infatuation with the Herculean ideal - after all, it is because the outsider judge fails to conform to our (albeit denied) image of the judge that she encounters the difficulties she does. In so doing, they act as portals through which to explore aspects of the judge and judging often overlooked or downplayed in conventional accounts of adjudication for example the role of connection, bias and narrative - encouraging us to reconsider Herculean notions of judging, which continue (despite arguments to the contrary) to shape and inform our understandings of the judge. Put another way, behind the improbable plots of these jurisprudential fairy tales lie counter-narratives - 'new perspective[s] . . . critically . . . illuminat[ing] ${ }^{124}$ the rhetoric of inclusiveness and difference proffered by the Department for Constitutional Affairs - in which diversity, unconstrained, penetrates the legal imagination. Subverting the intuitive appeal of attractive (yet ultimately limiting) images of the judge and judging, these narratives generate the possibility of new adjudicative adventures and with them, perhaps, a fairy tale ending to the woman judge's story.

In the meantime, did you hear about the father who likened his case before an apparently 'anti-father' and 'anti-man' female judge to 'sending the Ku Klux Klan to judge a black man'? ${ }^{125}$ Or about the Yale Law School alumnus who did not mind women studying or practising law - as long as they were 'ugly'? ${ }^{126}$

124. P Legrand 'Comparative legal studies and commitment to theory' (1995) 58(2) MLR 262 at 264.

125. Mills v Mills (unreported) SA 44 of 1996, 23 July 1996, discussed by R Graycar 'The gender of judgments: some reflections on "bias"' (1998) 32 UBCL Rev 1 at 6.

126. Quoted in H Garza Barred from the Bar - A History of Women in the Legal Profession (New York: Franklin Watt, 1996) p 12, referred to in McGlynn, above n 1, p 7. 